\title{
Political parallelism in Iceland
}

\author{
Perceived media-politics relations
}

\author{
Birgir Guðmundsson
}

Department of Social Science, University of Akureyri, Iceland

\begin{abstract}
My main objective in this article is to examine the importance of political parallelism in Iceland through establishing the extent to which political parallelism is perceived to characterise political communication in Iceland by politicians and voters. Political parallelism is one of the defining elements of Hallin and Mancini's typology of media systems. Based on candidate surveys from five elections and a voter survey, indexes of perceived political parallelism are configured for politicians and voters. The analysis suggests a high degree of perceived political parallelism and that the perceptions are reflected in partisan ideological views of individual media outlets. The same - or at least similar - perceptions about political parallelism in the media system seem to penetrate the system irrespective of age and at the national, local, and individual level of politics. However, voters and candidates of social democratic and liberal internationally oriented parties perceive a significantly lower degree of parallelism than others.
\end{abstract}

Keywords: political communication, political parallelism, media systems, elections, journalism

\section{Introduction}

Throughout the better part of the twentieth century, the Icelandic media system was characterised by a political party press, with four or five newspapers representing the Icelandic four-party system. The bourgeois press was, for most of that time, considerably stronger than the press to the left and centre. The state radio was, for all intents and purposes, held hostage by a political regulatory and surveillance board (Friðriksson, 2000; Guðmundsson, 2007, 2009). The unwinding of the hard grip of political parties on the press was a long process that spanned nearly forty years. The underlying driving force that characterised the evolution was a gradual emphasis on professionalisation that is, non-partisan independent journalism. As the new millennium dawned, formally ending the period of the political party press, an era of market media got underway, and more professional working methods were achieved in both media and politics. The private media scene in the era of market media has been characterised by ownership concentration with three or four major players dominating the biggest media. Telecom-

Guðmundsson, B. (2021). Political parallelism in Iceland: Perceived media-politics relations. Nordicom Review, 42(S2), 53-69. https://doi.org/10.2478/nor-2021-0017 
munication companies have become major stakeholders in broadcasting, and actors with strong relations to business and industries are heavily invested in the two daily newspapers. Competition is fierce in a small media and advertising market. No government subsidies had been given to private media companies until 2020, when modest assistance was offered due to the Covid-19 pandemic. The biggest single player in the market is the state-run public broadcaster RÚV, which operates two television channels, two radio stations, and a webpage, and competes on the market for both audiences and advertisements.

Iceland is a Nordic-style parliamentary democracy where there have traditionally been four established parties. These four parties combined have received more than 85 per cent of the votes in most elections since the beginning of the current party system in 1930s. This has radically changed in recent elections, and new parties are challenging the hegemony of the four established parties. The number of parties that stood in the 2013, 2016, and 2017 elections was unusually high; eleven parties stood in all six constituencies in the 2013 election and nine parties in the 2016 and 2017 elections. The traditional four parties are the conservatives (Independence Party); the agrarian, centre party (Progressive Party); the social democratic party (Social Democratic Alliance); and the socialist party (Left Greens). ${ }^{1}$ Majority governments have been the norm, with no formal blocks either on the left or right, and the established four parties have all participated in majority coalitions at some point (Harðarson, 2008). Turnout in Icelandic elections is high compared to other countries, and voter volatility has also been relatively high - most often over 10 per cent since 1971 . The Icelandic political system is party oriented with high party discipline (Harðarson, 2017).

The development of media and politics resembles what had happened in the larger Nordic countries where, based on the classification and typology of Hallin and Mancini (2004), a Nordic democratic corporatist model has been identified, characterised by political parallelism, a highly-developed newspaper market, a high degree of journalistic professionalism, and state intervention in the media market (Ørsten et al., 2008).

In this article, I examine the relations between media and politics in Iceland, with reference to Hallin and Mancini's three models of the media and politics. The Icelandic case is a Western and Nordic type of society, and thus questions regarding the universality (e.g., non-Western) and the comparative dimension of the three models will move back-stage (Hardy, 2008, 2012; Hallin \& Mancini, 2012; Norris, 2009). Similarly, de Albuquerque's (2018: 24) point that the very concept of political parallelism is not a "universally applicable analytical variable", but rather describes a peculiar pattern of relationship between media and political institutions, is duly noted. However, political parallelism is one of the defining dimensions in Hallin and Mancini's typology and is a meaningful analytical variable in the examination of Western democracies (Mancini, 2016). My main objective in this article is to examine the importance of political parallelism in Iceland through establishing the extent to which political parallelism is perceived to characterise political communication in Iceland by politicians and voters. In dealing with that question, I make use of extensive original data gathered around the last five elections in Iceland. These are surveys on the views and attitudes of both local and national politicians before the 2013, 2016, and 2017 parliamentary elections and the 2014 and 2108 municipal elections. In addition, I build on a general national poll in December 2015 for establishing the views of voters. 


\section{Parallelism in a digital age}

The concept of political parallelism originates in the writings of Seymour-Ure (1974) and Blumler and Gurevitch (1975/1995) on party-press relations. It referred to a pattern of relations between the printed press and political groups, where the press echoed the agenda and policies of the respective party. The concept developed from referring only to party-press parallelism into a more general political parallelism that refers to a situation where, in the words of de Albuquerque (2018: 2), "a significant degree of connection between particular media and political groups is a feature common enough to define the political communication system as a whole". He goes on to emphasise that for political parallelism to be a meaningful term for analysis two conditions must be fulfilled: on the one hand, that there is a political system characterised by competition between parties, and on the other hand, that the relations between media and politics are stable enough to enable identification of recurrent patterns (de Albuquerque, 2018). Both these conditions are, as was mentioned above, characteristic of the Icelandic and Nordic societies.

Hallin and Mancini suggest that the classical sense of party-politics parallelism is no longer relevant and use the concept in a broader sense, suggesting that the association between media and politics is not so much with particular parties, but rather "with general political tendencies" (Hallin \& Mancini, 2004: 29). By broadening the concept like that, two things happen: 1) it becomes more dynamic and responsive to the actual development of politics and media and 2) its complexity increases and it becomes more difficult to measure and operationalise. This is borne out in their account of a variety of components and indicators of political parallelism. These include media content, direct organisational connections, partisanship of media consumers, and, last but not least, elements of journalistic culture and professionalism, for example, journalistic activity and role orientations (Hallin \& Mancini, 2004). In other words, the political parallelism dimension in Hallin and Mancini's framework is a way to establish the nature of politics and media and the "balance between the advocacy and neutral/informational traditions of political journalism" (Hallin \& Mancini, 2004: 27). That balance, in turn, is closely related to the systemic distinction between internal plurality on the one hand, where social plurality is expressed within an individual medium, and external plurality on the other, where a plurality of views is achieved in the media system as a whole through the expression of a range of views in different media (Hallin \& Mancini, 2004).

One way of operationalising and tying together these different components and indicators is to examine and measure how each component is perceived in society and then create indexes of perceived parallelism. Such indexes would be based on opinions and estimates of politicians and voters on the partiality of the media, or internal versus external pluralism, giving a reasonable picture of the importance of political parallelism in the system. But it is not without limitations. One can expect that the perception of voters and politicians is in some ways different from factual or objective reality and skewed by the "hostile media phenomenon" that suggests political people tend to see media as hostile to their political cause (D'Alessio \& Allen, 2000; Vallone et al., 1985). Still, politics revolve around attitudes and beliefs, and politicians (and others) act and react in accordance with their perceptions and evaluations of situations in society. Political reality is thus largely a perceived reality, not least in political communication, and therefore indexes of perceived political parallelism are constructed below. This approach captures the importance of political parallelism in Iceland in an era when the direct 
measurable party-press relations, as well as party loyalty, have resided, globalisation has affected the media landscape, and new media have altered and challenged the logic of traditional media. According to Hallin and Mancini's (2004) predictions of the development of media systems, a convergence towards the liberal model was likely to occur, leading to increased professionalism and internal plurality, while external plurality and political parallelism would diminish. In the last decade, empirical evidence has highlighted changes in the media systems, suggesting a development in different directions (e.g., Brüggemann et al., 2014; Nord, 2008; Ohlsson, 2015; Strömbäck et al., 2008) and also that political parallelism is still important (Artero, 2015; van der Pas et al., 2017).

Nechushtai (2018) argues that individual countries might no longer fit into the ideal-type models, as the development of the media markets - for example, political parallelism or professionalism - has not led to predicted outcomes. Hybrid versions of different models might thus emerge, such as, for example, a "polarised liberal model" in the US - the very bastion of the liberal model. Such changes might call for a reconsideration of the ideal types - although the ideal types are quite useful and are likely to remain so for some time at least - but the typology can still be intact (Nechushtai, 2018). Nechushtai (2018) suggests that some elements of the partisan development in the US might be applicable to a more global context, and to be sure, some similar trends can be found in Iceland. She points out three factors that are both external and internal to the media development and have come to the forefront in recent years: 1) increased sociopolitical fragmentation and distrust in institutions; 2) a collapse of the economic model of legacy media; and 3) an internal change of the media through structural-digital transformation. All of these have in one way or another been felt in Iceland as well.

Increased sociopolitical fragmentation and distrust in institutions is reflected in more parallelism. This kind of development has been highly visible in Iceland after the financial meltdown in 2008, with a collapse in trust in government and increased party fragmentation (Harðarson, 2016, 2017). A collapse of the economic model of legacy media based on advertising has called for new forms of financing and has increasingly led to a definition of journalistic professionalism, both internationally and in Iceland, as organisational rather than occupational (Guðmundsson \& Kristinsson, 2017). An internal change of the media through structural-digital transformation has created new media conditions where different media logics are simultaneously at play in what Chadwick (2013) labelled a hybrid media system (see also Klinger \& Svenson, 2014), a condition found to be characteristic of Iceland (Guðmundsson, 2019). Mass media logic and network media logic interact and complicate state regulations, blur journalistic professional standards, undermine the economy of traditional media, further fragmentation, and create politicised digital media outlets.

In combination, these three elements prompt interest in political parallelism, as they create a renewed, but somewhat transformed, version of the phenomena. The structural relations between parties and the media that were shaped by traditional media logic have partly disappeared, while the more informal and ideological advocacy of hybrid network and traditional logics have taken over and remain strongly influenced by the historical proximity of the party-press legacy (Guðmundsson, 2019; Harðarson, 2008). Evidence from a study of the 2013 Icelandic parliamentary elections points to a phenomenon of "political market media", where connections exist between commercial media and political interests (Guðmundsson, 2013). Thus, an examination of the changes in and forms 
of political parallelism casts an important light on the development and characteristics of the Icelandic model of media and politics.

\section{Hypotheses}

Following the suggestion of a "political market media" (Guðmundsson, 2013), a hypothesis can be generated about political parallelism in Iceland:

H1. A perception of a high degree of political parallelism can be found among Icelandic national and local politicians and among the Icelandic voters.

As political parallelism in this study refers to general political trends and ideologies, it is more likely to be felt at the national level than the local level. In national politics, general trends and political ideology play a bigger role than they do in local elections, where practical and place-specific questions are more often the object of political discussion (Kristinsson, 2006). Thus, the second hypothesis reads as follows:

$\mathrm{H} 2$. The perception of political parallelism is not as strong at the level of local politicians as it is in national politics.

The fragmentation in the Icelandic party system that has occurred in the last decade has complicated the party-press parallelism that dominated the media system for the latter part of the twentieth century. However, the historical proximity of the old system is likely to influence the perception of the present situation. While this historical proximity is likely to be felt among all politicians and voters, new and small parties, and their candidates, are likely to be more sensitive to and less happy with political affiliations of the media. On that assumption, the third hypothesis is put forth as follows:

H3. Candidates of new and small parties perceive the degree of political parallelism stronger than do candidates of the established parties.

Similarly, following up on the historical proximity of the party-political media system, older candidates and voters are likely to have been socialised into that system and thus might not find it as disturbing as younger candidates and voters do that independent market-driven media is a more desirable norm. In that light, the fourth hypothesis suggests the following:

H4. Younger candidates and voters perceive political parallelism to a higher degree than do older candidates and voters.

Finally, if perception of political parallelism is generally high in the Icelandic media system, it follows that a certain correlation would be found between individual media and political ideology, and even certain political parties, again considering the historical proximity of the party-political media. If such patterns are identified among local and national politicians and voters in general, they can be seen as an expression of how parallelism is perceived within the whole media system. In order to establish the validity of this suggestion, a fifth hypothesis is put forth:

H5. Patterns of perceived political parallelism among both voters and candidates are reflected along partisan lines, so that those who share certain ideological characteristics classify different media outlets in the same or similar manner. 


\section{Methods and instruments}

In approaching the object of this study and testing the hypotheses, two main types of original data were used: first, web-based candidate surveys before the 2013, 2016, and 2017 parliamentary elections and a similar survey before the 2014 and 2018 municipal elections; and second, a sample survey among the Icelandic population based on the sample panel of the Social Science Research Institute.

All five web-based candidate surveys dealt with political communication and included more questions than discussed here. These were population surveys - not sample surveys - in the sense that the whole population under study received it. In the case of the parliamentary elections, five to seven top candidates of every party list in all constituencies received the surveys - or all candidates that might have had a theoretical possibility of becoming a member of parliament or a deputy member. In the case of the municipal elections, ten large and medium sized municipalities - including Reykjavík, the capital - were selected, and the top three to seven candidates (depending on the size of the municipality) of all party lists received the survey. The overall response rate for all the surveys was just over 60 per cent, but the response rate for some of the questions was somewhat lower, even down to 40 per cent. Nevertheless, it must be considered satisfactory, as these were not sample surveys, and the group of respondents reflected well the population in terms of parties, constituencies, gender, and age.

The questions under review were the same in all five candidate surveys and revolved around the attitudes of politicians to internal pluralism of the Icelandic media. Five questions in the survey were used to assess different aspects of the confidence of politicians in internal pluralism or their perception of political parallelism: ${ }^{2}$

1. How important or unimportant do you think it is for a political party to have its own political organ? (Options given on a 5-point Likert scale.)

2. Do you think traditional Icelandic media today (broadcast and print) to be generally independent from political parties? (Options given on a 5-point Likert scale.)

3. If the impartiality or bias of national traditional news media (excluding editorials) was to be evaluated on a scale from $1-5$, where $1=$ completely impartial and $5=$ very strongly biased, what rating would you give the following media: Fréttablaðið, Morgunblaðið, DV, Viðskiptablaðið, RÚV, Channel 2/Bylgjan, Kjarninn, Stundin?

4. How much do you agree or disagree with the following statement: "The news values of journalists and reporters in larger national media with respect to political reporting are shaped primarily by general professional journalist considerations". (Options given on a 5-point Likert scale.)

5. If it was to be estimated in what direction a possible bias in news values of these national media goes, how would you classify each of these on a left-right axis? (Options given: supports left policies; supports the left-centre policies; supports centre policy; supports right-centre policies; supports right policy; supports no single policy more than others.)

The first four questions were designed to measure different aspects of confidence or lack of confidence in internal pluralism, or to measure, when combined, the perceived degree 
of political parallelism. Thus, the answers to these questions (1-4) were merged into an index, or criterion, for the degree of perceived political parallelism. By operationalising the concept of political parallelism through this criterion, important information from within the political system is obtained. The fourth question was designed to deepen the understanding of parallelism and measure how it is reflected with respect to individual media.

However, in order to get a fuller picture of the perception of political parallelism, the role of voters is also important. The sample survey among the Icelandic voters consisted of two questions in the November/December 2015 panel of the Social Science Research Institute. The survey was a web panel, with a net sample of 1,428 persons. There were 884 answers, yielding a response rate of 62 per cent. The data was weighted with respect to age, sex, place of living, and education. The questions asked were the following:

1. How much do you agree or disagree with the following statement: "The news values of journalists and reporters in larger national media with respect to political reporting are shaped primarily by general professional journalist considerations". (Options given on a 5-point Likert scale.)

2. Now we would like to ask about your evaluation of the impartiality or bias of national traditional news media (excluding editorials). Using a five-point scale - very biased; rather biased; neither biased nor impartial; rather impartial; very impartial - where would you place the following media: Fréttablaðið, Morgunblaðið, DV, Viðskiptablaðið, RÚV, Channel 2/Bylgjan?

As can be seen, these questions are comparable to the questions used in the candidate survey, and here, too, a perceived political parallelism criterion was created. This was done by merging the results from the former question with the aggregate results from the second question. The results regarding individual media in question number two, on the other hand, are comparable to the fifth question in the candidate survey.

\section{Results}

When the candidate surveys from the five elections and the voter survey are considered together, the results show a high degree of perceived political parallelism in Iceland. However, there is some variance between elections and types of elections and between politicians and voters. Candidates in the five elections and voters show a similar tendency with regards to perceived political parallelism. As expressed in Figure 1, some 60 per cent of the candidates score high or rather high on the political parallelism perception criterion, while the comparable number for voters is 41 per cent. It must be stressed that the two criterions are not identical, calling for caution in making a direct comparison. Yet, in both cases, only a very small minority of candidates, and a somewhat larger minority of voters, seems to perceive low or rather low political parallelism in the system. 
Figure 1 Perceived degree of parallelism by candidates and voters

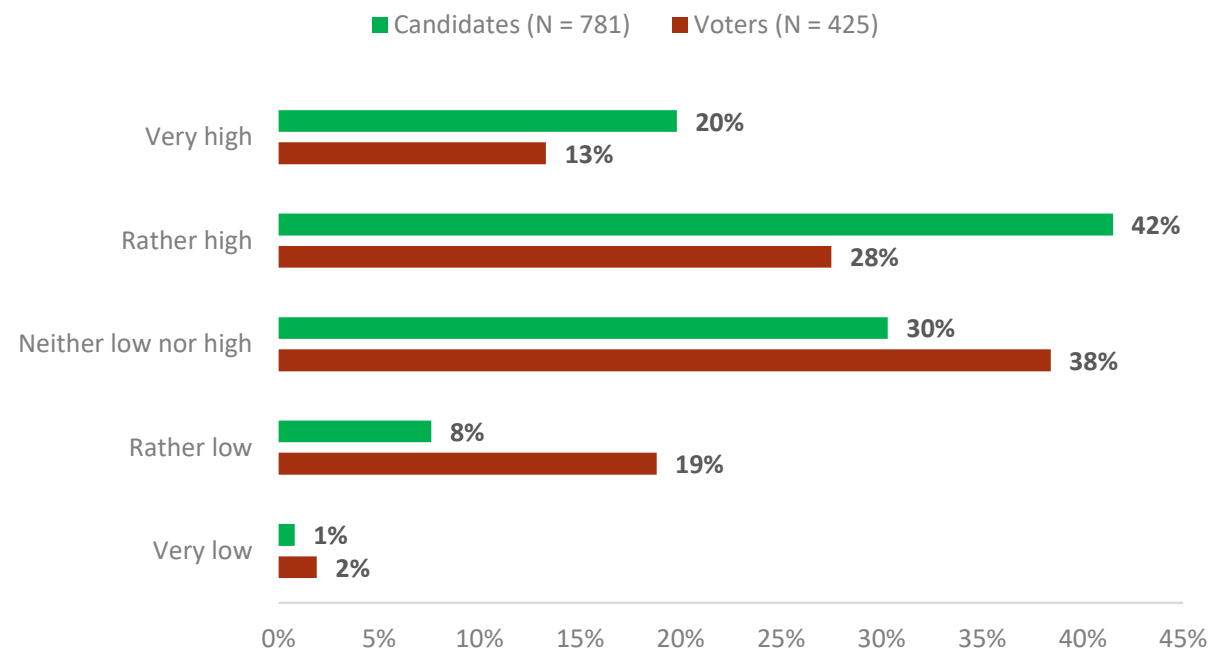

Comments: Findings based on voter's survey and five elections.

Hypothesis 1, which stated that a high degree of perceived parallelism would be found among candidates and voters, receives support in the data. Considerably more candidates perceive high or rather high parallelism than perceive low or rather low parallelism. The same thing applies to the voters, although the division is not as categorical.

There are other interesting differences concealed in these aggregate numbers. A change seems to have occurred over time, at least in the parliamentary elections. In Figure 2, it becomes apparent that candidates in the most recent parliamentary elections of 2017 perceive less political parallelism than in the 2013 elections.

Figure 2 Perceived parallelism by elections

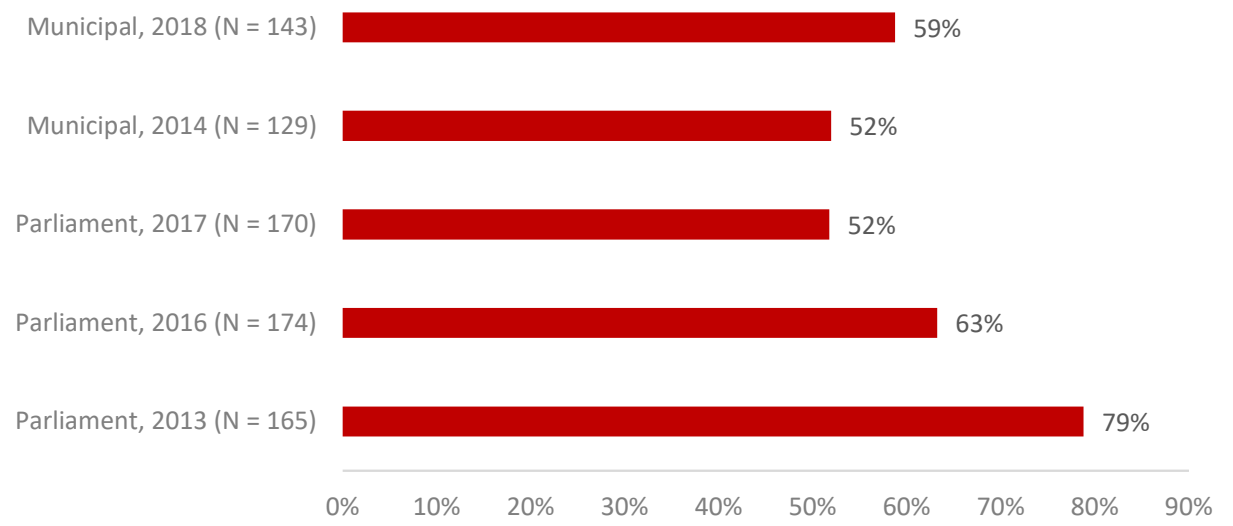

Comments: Candidates that score very high and rather high.

A linear regression was used to see if perceived parallelism among candidates in the 2013 elections was different from the other elections. All elections were dummy-coded and the 
2013 election used as a reference variable. A significant regression equation was found $[F(4,776)=13,413 ; p<.000]$ with an $R^{2}$ of .065 . Perceived parallelism is significantly higher for the elections in 2013 than in all the following elections.

Table 1 Comparison of perceived parallelism in elections

\begin{tabular}{lccccc}
\hline & $\begin{array}{c}\text { Unstandardised } \\
\text { coefficients (B) }\end{array}$ & $\begin{array}{c}\text { Std. } \\
\text { error }\end{array}$ & $\begin{array}{c}\text { Standardised coef- } \\
\text { ficients (Beta) }\end{array}$ & $\boldsymbol{t}$ & Sig. \\
\hline (Constant) & 3.845 & 0.049 & - & 77.711 & 0 \\
Parliament, 2016 & -0.269 & 0.069 & -0.171 & -3.899 & 0 \\
Parliament, 2017 & -0.412 & 0.069 & -0.259 & -5.926 & 0 \\
Municipal, 2014 & -0.473 & 0.075 & -0.268 & -6.331 & 0 \\
Municipal, 2018 & -0.37 & 0.073 & -0.218 & -5.096 & 0 \\
\hline
\end{tabular}

Comments: The table shows a linear regression model for perceived parallelism in different elections, where the 2013 elections are a reference variable. See Appendix 1 for other elections as a reference.

When the regression was repeated using different elections as reference variables, it was established that the decrease in perceived parallelism from 2013 to 2016 and 2016 to 2017 was significant in all cases. The elections were of a different nature - municipal elections and parliamentary elections. The increase in perceived parallelism between the municipal elections of 2014 and 2018 was, however, not statistically significant (see Appendix 1).

Hypothesis 2 expected the perception of parallelism to be higher among national candidates than among candidates standing in the municipal elections. As stated above, this was the case the 2013 elections (elections that stand out somewhat in terms of perceived parallelism), when perceived parallelism was higher than in both the 2014 and 2018 municipal elections. In addition, there was a statistically significant higher perception of parallelism in the 2016 parliamentary elections than in the 2014 municipal elections. Apart from that, the data does not conclusively support Hypothesis 2, and perceived parallelism, still measured quite high, has over time become more alike in local and national elections (see Appendix 1).

Hypothesis 3 expected a higher degree of perceived parallelism with candidates of new and smaller parties than with those of established parties. Hypothesis 4 expected that both voters of small and new parties and young candidates and voters would score higher in perceived parallelism than older candidates and voters. To test these hypotheses, a multiple linear regression was used to predict perceived parallelism by candidates, on the one hand, and voters, on the other, based on age and party, and in the case of the candidate surveys, controlling for the time and type of elections.

In the case of voter's perception, the regression equation found was $[F(2,341)=$ 1,$774 ; p=171$ ) and a $R^{2}$ of .010 . The results thus show that neither "age" nor "party voted for" significantly predicts perceived parallelism among voters ( $p=.075$ for party and $p=.447$ for age). However, further analysis and comparison of the voters of different parties show that voters of the Social Democratic SDA and the Bright Future Party (both being liberal social democratic parties) perceive statistically less parallelism than the voters of the largest party, the centre-right Independence Party. The voters of these two parties also show a lower degree of perceived parallelism than other voters (Beta $=-0.088 \mathrm{sd}$.; Beta $=-0.124 \mathrm{sd}$.). 
Table 2 Perceived parallelism in parties

\begin{tabular}{lccccc}
\hline & $\begin{array}{c}\text { Unstandardised } \\
\text { coefficients (B) }\end{array}$ & $\begin{array}{c}\text { Std. } \\
\text { error }\end{array}$ & $\begin{array}{c}\text { Standardised } \\
\text { coefficients (Beta) }\end{array}$ & $\boldsymbol{t}$ & Sig. \\
\hline (Constant) & 3.33 & 0.086 & - & 38.627 & 0 \\
Bright Future & -0.459 & 0.262 & -0.088 & -1.753 & .08 \\
Progressive Party & -0.112 & 0.131 & -0.051 & -0.854 & .393 \\
Alliance Party & -0.428 & 0.183 & -0.124 & -2.333 & .02 \\
Left Green Party & 0.248 & 0.177 & 0.075 & 1.401 & .162 \\
Pirate Party & 0.065 & 0.109 & 0.039 & 0.597 & .551 \\
Other parties & -0.068 & 0.155 & -0.024 & -0.437 & .662 \\
Excluded & 0.025 & 0.12 & 0.013 & 0.213 & .831 \\
\hline
\end{tabular}

Comments: As this coefficients table for the dependent variable "perceived political parallelism”, with the Independence Party as a reference variable, demonstrates, the Social Democratic Alliance and Bright Future voters show a significantly lower degree of perceived parallelism than the Independence Party voters, and also lower than the voters of other parties.

This suggests that the perception of political parallelism is general among the voter population and not confined to certain age groups or political affiliations, except for SDA and Bright Future voters, who are likely to perceive less parallelism than other voters. This does, however, only partly inform about how this perception manifests itself among different parts of the electorate, a question we shall return to below.

Returning to the candidate surveys, it is apparent that the age of candidates does not predict perceived parallelism

Table 3 Perceived parallelism (controlling for age and time of elections)

\begin{tabular}{lclccc}
\hline & $\begin{array}{c}\text { Unstandardised } \\
\text { coefficients }(\boldsymbol{B})\end{array}$ & $\begin{array}{l}\text { Std. } \\
\text { error }\end{array}$ & $\begin{array}{c}\text { Standardised coef- } \\
\text { ficients (Beta) }\end{array}$ & $\boldsymbol{t}$ & Sig. \\
\hline (Constant) & 3.522 & 0.1 & - & 35.155 & 0 \\
Bright Future & -0.251 & 0.101 & -0.105 & -2.485 & .013 \\
Peoples Party & 0.248 & 0.128 & 0.076 & 1.938 & .053 \\
Progressive Party & 0.094 & 0.085 & 0.052 & 1.111 & .267 \\
Centre Party & 0.234 & 0.143 & 0.062 & 1.635 & .102 \\
Pirate Party & 0.02 & 0.097 & 0.009 & 0.208 & .836 \\
Alliance Party & -0.433 & 0.103 & -0.177 & -4.208 & 0 \\
Left Green Party & -0.043 & 0.088 & -0.022 & -0.481 & .631 \\
Reconstruction Party & -0.388 & 0.111 & -0.144 & -3.489 & .001 \\
Other parties & 0.142 & 0.082 & 0.088 & 1.728 & .084 \\
\hline
\end{tabular}

Comments: This coefficients table shows the aggregate degree of perceived political parallelism of candidates in five elections with the Independence Party as a reference, controlling for time of elections and age.

Here, too, a multiple linear regression was used to predict perceived parallelism by candidates based on party, using dummy-coded party variables, where the Independence Party was a reference variable, and controlling for elections and age. A significant regression equation was found $[F(15,762)=9,055 ; p<.000]$, with a $R^{2}$ of .151 . As is expressed in the coefficients table (see Table 3 ) the Beta values in perceived parallelism are both higher and lower than the values for the Independence Party. A statisti- 
cally significant lower score than for the Independence Party is only measured for the Bright Future Party, Social Democratic Alliance, and Reform Party. The highest standardised Beta values are for two new parties that stood for the first time in the 2017 elections - the Centre Party (Beta $=.062$ standard deviation) and the People's Party $($ Beta $=.076$ standard deviation $)-$ and for the variable "other parties" (Beta $=.082$ standard deviation). The difference between these parties and the Independence Party is, however, not significant. Three parties - the Progressive Party, the Pirate Party, and the Left Green Party - seem to group together in the vicinity of the reference party, the Independence Party.

This is indeed interesting, as these are three of the four traditional parties of the party system, with the addition of the Pirate Party. Of the established four parties of the party system (Independence Party, Progressive Party, Social Democratic Alliance, and Left Green Party), only the Social Democratic Alliance candidates score very differently than the others. The Pirates thus seem to be closer to the old parties in perception of political parallelism at the centre of the spectrum, while the more liberal, international, social democratic parties (the Alliance Party, Bright Future, and Reconstruction Party) occupy the lower end of the perceived parallelism spectrum. The more nationalistic parties (Centre Party and Peoples Party) and new and small parties (others) are at the upper end. This tentatively suggests an ideological dimension in the perception of political parallelism. The established parties and the Pirate Party can be seen as firmly embodied in the established political culture and perceive a moderate degree of parallelism. New parties - mostly with a somewhat centre-right populist nationalistic approach - perceive high political parallelism, while liberal social democratic parties with an international emphasis perceive low political parallelism. It is interesting to note that the relatively new Pirate Party comes up with similar scores as the old parties. Here, the impact of new media in Pirate ideology might be stronger than with other parties, and new media perceived as less politically connected than old media.

Hypothesis 5 suggested that political parallelism perceptions of both voters and candidates would be reflected along partisan lines, so that those who share certain ideological characteristics would classify different media outlets in the same or similar manner. These patterns were examined in the fifth question of the candidate surveys as well as in the question asking for an evaluation of the impartiality or bias of national traditional news media in the voter's survey. In the candidate surveys, the question posed asked for a classification of media on the left-right continuum, or whether a medium favoured any political position more than another. Results from the classification of national and local politicians as to what different media can be said not to support one position on a left-right continuum more than another can be seen in Figure 3. 
Figure 3 Candidates who claim that a medium supports no one policy more than another

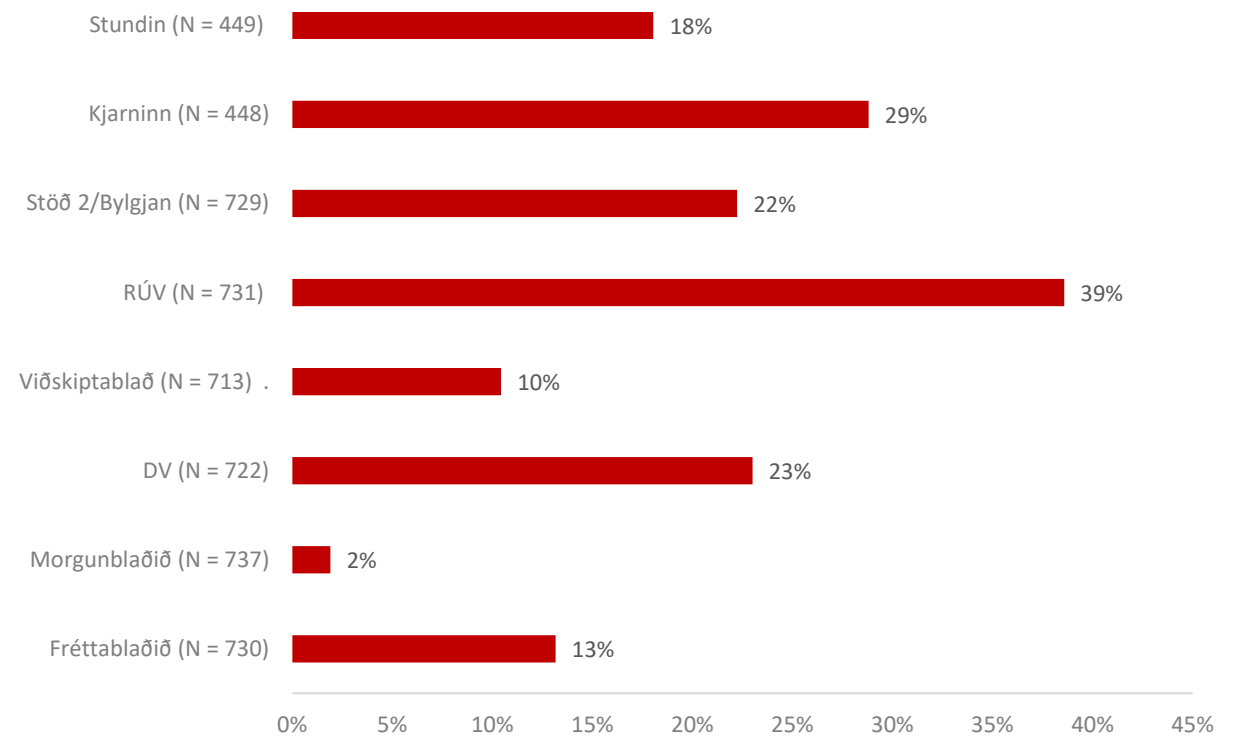

Comments: The figure shows the percentage of candidates in all five elections that say the relevant medium supports no one policy more than another. Two of the mediums asked about, Stundin and Kjarninn, are relatively new Internet-based media that are self-proclaimed as independent and focus heavily on politics. They were added to the surveys in the 2016 elections. RÚV, the state broadcasting service, is by far perceived the least ideologically biased, while the subscription daily Morgunblaðið is considered by almost everybody as ideologically slanted to the right.

As can be seen from Figure 3, RÚV entertains a somewhat unique position among politicians, to the extent that almost two out of every five candidates in the last five elections held in Iceland believed RÚV's newsroom not to support any policy more than another. Generally, the views of candidates are considerably diverse, but the views of national politicians about the political position of individual media outlets have gradually become more like the attitudes of the local politicians.

A closer analysis of the responses in all five surveys reveals a certain pattern in the mean variance of how politicians from different parties evaluate the political stand of individual media. The centre-left parties (Social Democratic Alliance and Left Green Party) tend to situate Stöð 2, Morgunblaðið, and Viðskiptablaðið further to the right than other media and perceive $D V$ and RÚV to be relatively neutral. The centre-right parties (Progressive Party and Independence Party), on the other hand, tend to believe Viðskiptablaðið and Stöð 2/Bylgjan, and even to an extent Morgunblaðið, to be somewhat neutral, but RÚV and $D V$ to be rather left-wing news outlets. A one-way anova test shows that the effect of the party of a candidate was significant for predicting the view on political stand of media outlets in all cases (see Table 4). 
Table 4 Candidate views on media position

\begin{tabular}{lll}
\hline Media outlet & \multicolumn{1}{c}{$\boldsymbol{F}$-ratio (df) } & Sig. \\
\hline Fréttablaðið & $F(9 ; 720)=7.072$ & .00 \\
Morgunblaðið & $F(9 ; 727)=9.181$ & .00 \\
DV & $F(9 ; 727)=6.318$ & .00 \\
Viðskiptablaðið & $F(9 ; 709)=2.624$ & .05 \\
RúV & $F(9 ; 721)=29.148$ & .00 \\
Stöð 2/Bylgjan & $F(9 ; 719)=9.375$ & .00 \\
Kjarninn & $F(9 ; 438)=10.813$ & .00 \\
Stundin & $F(9 ; 439)=5.087$ & .00 \\
\hline
\end{tabular}

Comments: The table shows the results of a one-way anova test for the effect of a candidate's party on a candidate's view on political stand of different media in the combined results for all five elections. The effect is significant for all media. F(df between groups; df within groups) = F-ratio.

The state broadcasting company, RÚV, was overall believed to be more impartial than other media (see Figure 3), but views of candidates of different parties towards the station are, however, quite divided, as the high $F$-ratio (29.148) bears witness to.

The latter questions in the voters' survey were about voter perception of partiality or impartiality of particular media. It is interesting to note that a similar pattern emerges with the voters and the politicians with respect to the effect of party voted for and the perceived impartiality of different media. A comparison of mean partiality and impartiality ratings of voters of the different parties reveals that voters of the centre-right parties (Independence Party and Progressive Party) tend to rate RÚV and Fréttablaðið as more partial, and Viðskiptablaðið and Morgunblaðið as more impartial, than voters of other parties. At the same time, voters of the centre-left parties (Social Democratic Alliance, Bright Future Party, and Left Green Party) tend to rate RÚV and Fréttablaðið as impartial and Morgunblaðið and Viðskiptablaðið as partial. There does not appear as clear a division with the voters as with the politicians in relation to the partiality of Stöð 2/Bylgjan and $D V$. However, a one-way anova test of the effect of party voted for on the voter's opinion on impartiality is significant for all media.

Table 5 Voters' views on media position

\begin{tabular}{lll}
\hline Media outlet & $\boldsymbol{F}$-ratio (df) & Sig. \\
\hline Fréttablaðið & $F(15 ; 514)=5.760$ & .000 \\
Morgunblaðið & $F(15 ; 524)=10.758$ & .000 \\
DV & $F(15 ; 496)=5.294$ & .000 \\
Viðskiptablaðið & $F(14 ; 370)=2.097$ & .011 \\
Fréttastofa RúV & $F(15 ; 532)=5.757$ & .000 \\
Stöð2 / Bylgjan & $F(15 ; 506)=2.238$ & .005 \\
\hline
\end{tabular}

Comments: Results of a one-way anova test for the effect of a voter's choice of party on a voter's view on political stand of different media in the 2016 parliamentary elections. The effect is significant for all media. The lines in the table stand for the following: $F$ ( $d f$ between groups; $d f$ within groups) $=$ F-ratio. 


\section{Discussion}

Although political parallelism in the form of a formal party press was abandoned in Iceland in the late twentieth century and replaced with a market media system, (Guðmundsson, 2007; Harðarson, 2008), this study has shown that ties between media and politics are still very much alive. A coexistence between market media, journalistic professionalism, active state regulation, and political parallelism is, however, one of the defining characteristics of the democratic corporatist ideal type model. While evaluating the interaction of these factors in the case of Iceland, the point is not if such a coexistence is in place, but rather the degree to which (for the purpose of this article) parallelism determines the relations between media and politics. The data presented above suggests that this influence is considerable and defining for the particular media model in Iceland.

Hallin and Mancini (2012) suggested that the forces of change, commercialisation, and technological development affected journalistic professionalism and political parallelism in a direction of convergence with the liberal model. Evidence of that is clearly apparent in the development of political communication in Iceland since the turn of the century. Attention must furthermore be drawn to the point that although forces of change - that is, professionalisation, commercialisation, and technological innovation - are of a global nature, their effect and implementation is felt in a unique way within a particular country and shaped by structural and systemic factors that are deeply rooted in values, culture, and history (Hallin \& Mancini, 2012; Ohlsson, 2015; Ørsten et al., 2008). Thus, country-specific versions of important variables matter for the way in which global forces manifest themselves in Iceland. A rapid phase of change and historical proximity to the system of party media, a lack of state regulations for the media market in the transitional period, in conjunction with a relative infancy of journalistic professionalism, created in Iceland a development that points to convergence with some important characteristics of the polarised pluralist model. These characteristics are highlighted in this study through the findings that in Iceland, there is widely perceived and visible patterns of political parallelism. While the abstract, ideal type suggests that the impact of commercialisation would lead to convergence with the liberal model - that is, internal pluralism and less political parallelism - this development takes on a blurred form in the Icelandic context: a hybrid between all three models, a democratic corporatist model with strong elements of the liberal and polarised pluralist models.

Indeed, similar twists have been suggested with reference to the US, where some commercial media companies have become strongly affiliated with political orientations and candidates. Paolo Mancini (2013) pointed out that commercialisation and the ensuing audience fragmentation impacted political parallelism with respect to polarising developments, both in the US and in Italy. More recently, it has been suggested that the liberal model itself, in the US, is undergoing a transformation where polarisation and ideological political parallelism have become characteristic of the media system. Applying the Hallin and Mancini's typology in the context of sociopolitical change and external and internal media development has led Nechushtai (2018) to coin the phrase "polarised-liberal model". As pointed out above, many similar elements of change are at work outside the US, including in Iceland. These include increased social and political fragmentation and distrust in institutions, undermining of the economic model of traditional media, and a structural-digital transformation of the media and a creation of a hybrid media system. Considering the rapid phase of change in communication since 
Hallin and Mancini's model and its Nordic version were put forth, the point made by Ohlsson (2015) that there is no longer a meaningful Nordic or democratic corporatist model in the Nordic countries, and in light of the continuous importance of political parallelism in Iceland that is revealed in this study, a revision of the model seems inevitable.

It is not the analytical framework that needs revision, but rather the ideal types of the model and the direction and nature of the convergence it produces. While the framework allows for dynamic developments and interpretations over time, the ideal types tend to be static and unclear when compared to actual empirical data at different times. The authors of Communicating Politics: Political Communication in the Nordic Countries (Strömbäck et al., 2008) - a Nordic version of Hallin and Mancini's model - considered diminishing political parallelism a likely effect of increased commercialisation, but already in 2008 had some reservations. Looking to developments in the US, they pointed out that it "follows that commercialism - no matter how consequential it is for media around the world - is not necessarily at odds with political parallelism and external pluralism" (Strömbäck et al., 2008: 20). Thus, it is safe to conclude, based on the data, that the version of the democratic corporatist model is found in Iceland has some important features that resemble not only the liberal model, but also the Mediterranean model.

\section{Notes}

1. According to the 2017 election study in Iceland, voters ranked the parties in the following way on the left-right continuum $(0=$ furthest to the left and $10=$ furthest to the right): Left Green Movement (2.3); Social Democratic Alliance (3.5); Pirates (3.6); People's Party (4.7); Progressive Party (5.7); Centre Party (6.1); Reconstruction Party (6.3); Independence Party (8.4) (Íslenska kosningarannsóknin, 2017).

2. A note should be made that in the 2016 questionnaire and onward, more media were added, but these are new net-based media that extensively cover politics and economics.

\section{References}

Artero, J. P. (2015). Political parallelism and media coalitions in western Europe [Working paper]. Oxford: Reuters Institute for the Study of Journalism, University of Oxford.

Blumler, J. G., \& Gurevitch, M. (1995). Towards a comparative framework for political communication. In J. G. Blumler, \& M. Guruvitch (Eds.), The crisis of public communication. London: Routledge. (Original work published 1975). https://doi.org/10.4324/9780203181775

Brüggemann, M., Engesser, S., Büchel, F., Humprecht, E., \& Castro, L. (2014). Hallin and Mancini revisited: Four empirical types of western media systems. Journal of Communication, 64(6), 1037-1065. https:// doi.org/10.1111/jcom. 12127

Chadwick, A. (2013). The hybrid media system: Politics and power. New York: Oxford University Press. https://doi.org/10.1093/acprof:oso/9780199759477.001.0001

D’Alessio, D., \& Allen, M. (2000). Media bias in presidential elections: A meta-analysis. Journal of Communication, 50(4), 133-156. https://doi.org/10.1111/j.1460-2466.2000.tb02866.x

de Albuquerque, A. (2018). Political parallelism. In Oxford research encyclopedia of communication. https:// doi.org/10.1093/acrefore/9780190228613.013.860

Friðriksson, G. (2000). Nýjustu fréttir! Saga fjölmiðlunar á Íslandi frá upphafi til vorra daga [The latest news! Icelandic media history]. Reykjavik: Iðunn

Guðmundsson, B. (2007). Inngangur - Í spegli tímans [Introdution - Looking in the mirror of time]. In B. Guðmundsson (Ed.), Íslenskir blaðamenn: Sjónarmið handhafa blaðamannaskírteina 1-10 á 110 ára afmæli Blaðamannafélags Íslands [Views of journalists that hold union cards number 1-10] (pp. 6-17). Reykjavik: Blaðamannafélag.

Guðmundsson, B. (2013). Pólitísk markaðsfjölmiðlun [Political market media]. Stjórnmal og Stjórnsýsla, $9(2), 509-530$.

Guðmundsson, B. (2019). Logics of the Icelandic hybrid media system: Snapchat and media-use before the 2016 and 2017 Althing elections. Nordicom Review, 40(1), 43-59. https://doi.org/10.2478/nor-2019-0001

Guðmundsson, B., \& Kristinsson, S. (2017). Journalistic professionalism in Iceland: A framework for analysis and an assessment. Journalism, 20(12), 1684-1703. https://doi.org/10.1177/1464884917695416 
Hallin, D. C., \& Mancini, P. (2004). Comparing media systems: Three models of media and politics. Cambridge: Cambridge University Press. https://doi.org/10.1017/CBO9780511790867

Hallin, D. C., \& Mancini, P. (2012). Comparing media systems: A response to critics. In F. Esser, \& T. Hanitzsch (Eds.), Handbook of comparative communication research (pp. 207-220). New York: Routledge. https://doi.org/10.4324/9780203149102

Hardy, J. (2008). Western media systems. London: Routledge. https://doi.org/10.4324/9780203869048

Hardy, J. (2012). Comparing media systems. In F. Esser \& T. Hanitzsch (Eds.), Handbook of comparative communication research (pp. 185-205). New York: Routledge. https://doi.org/10.4324/9780203149102

Harðarson, Ó. P. (2008). Political communication in Iceland. In J. Strömbäck, M. Ørsten, \& T. Aalberg (Eds.), Communicating politics: Political communication in the Nordic countries (pp. 63-82). Gothenburg: Nordicom, University of Gothenburg.

Harðarson, Ó. P. (2016). Iceland 2016: Major changes - but not a revolution. Party Systems and Governments Observatory. http://whogoverns.eu/iceland-2016-major-changes-but-not-a-revolution/

Harðarson, Ó. P. (2017). Icelandic Althingi election 2017: One more government defeat - and a party system in a continuing flux. Party Systems and Governments Observatory. https://whogoverns.eu/icelandicalthingi-election-2017-one-more-government-defeat-and-a-party-system-in-a-continuing-flux/

Íslenska kosningarannsóknin [Icelandic election study]. (2017). Databank, Félagsvísindastofnun. https://fel. hi.is/is/islenska-kosningarannsoknin-2017

Klinger, U., \& Svenson, J. (2014). The emergence of network media logic in political communication: A theoretical approach, New Media \& Society, 17(8), 1241-1257. https://doi.org/10.1177/1461444814522952

Kristinsson, G. H. (2006). Íslenska stjórnkerfið [The Icelandic system of government]. Reykjavík: Háskólaútgáfan.

Mancini, P. (2013). Media fragmentation, party system, and democracy. The International Journal of Press/ Politics, 18(1), 43-60. https://doi.org/10.1177/1940161212458200

Mancini, P. (2016) Parallelism, Political. In G. Mazzoleni (Ed.), The international encyclopaedia of political communication. Wiley Online Library. https://doi.org/10.1002/9781118541555

Nechushtai, E. (2018). From liberal to polarized liberal? Contemporary U.S. news in Hallin and Mancini's typology of news systems. The International Journal of Press/Politics, 23(2), 183 -201. https://doi. org/10.1177/1940161218771902

Nord, L. (2008). Comparing Nordic media systems: North between west and east? Central European Journal of Communication, (1), 95-110.

Norris, P. (2009). Comparative political communications: Common frameworks or Babelian confusion? Government and Opposition, 44(3), 321-340. https://www.jstor.org/stable/44484640

Ohlsson, J. (2015). The Nordic media market 2015: Denmark, Finland, Iceland, Norway, Sweden. Gothenburg: Nordicom, University of Gothenburg.

Seymour-Ure, C. (1974). The political impact of the mass media. Beverly Hills, California: Sage

Strömbäck, J., Ørsten, M., \& Aalberg, T. (2008). Political communication systems in the Nordic countries: An introduction (pp. 11-24). In J. Strömbäck, M. Ørsten, \& T. Aalberg, (Eds.), Communicating politics: Political communication in the Nordic countries. Gothenburg: Nordicom, University of Gothenburg.

Vallone, R. P., Ross, L., \& Lepper, M. R. (1985). The hostile media phenomenon: Biased perception and perceptions of media bias in coverage of the Beirut massacre. Journal of Personality and Social Psychology, 49(3), 577-585. https://doi.org/10.1037/0022-3514.49.3.577

van der Pas, D. J., van der Brug, W., \& Vliegenthart, R. (2017). Political parallelism in media and political agenda setting. Political Communication, 34(4), 491-510. https://doi.org/10.1080/10584609.2016.12 71374

Ørsten, M., Aalberg, T., Strömbäck, J. (2008). Conclusions: Similarities and differences between the Nordic countries. In J. Strömbäck, M. Ørsten, \& T. Aalberg (Eds.), Communicating politics: Political communication in the Nordic countries (pp. 267-272). Gothenburg: Nordicom, University of Gothenburg.

(C) 2021 Nordicom and respective authors. This is an Open Access work licensed under the terms of the Creative Commons Attribution-NonCommercial-NoDerivatives 4.0 International Public licence (CC BY-NC-ND 4.0). To view a copy of the licence, visit https://creativecommons.org/ licenses/by-nc-nd/4.0/ 


\section{Appendix 1}

\begin{tabular}{|c|c|c|c|c|c|}
\hline & $\begin{array}{l}\text { Unstandardised } \\
\text { Coefficients (B) }\end{array}$ & $\begin{array}{l}\text { Std. } \\
\text { Error }\end{array}$ & $\begin{array}{c}\text { Standardised } \\
\text { Coefficients } \\
\text { (Beta) }\end{array}$ & $t$ & Sig. \\
\hline \multicolumn{6}{|c|}{ Parliamentary elections, 2013 as reference } \\
\hline (Constant) & 3.845 & 0.049 & - & 77.711 & 0 \\
\hline Parliament, 2016 & -0.269 & 0.069 & -0.171 & -3.899 & 0 \\
\hline Parliament, 2017 & -0.412 & 0.069 & -0.259 & -5.926 & 0 \\
\hline Municipal, 2014 & -0.473 & 0.075 & -0.268 & -6.331 & 0 \\
\hline Municipal, 2018 & -0.37 & 0.073 & -0.218 & -5.096 & 0 \\
\hline \multicolumn{6}{|c|}{ Parliamentary elections, 2016 as reference } \\
\hline (Constant) & 3.576 & 0.048 & - & 74.214 & 0 \\
\hline Parliament, 2013 & 0.269 & 0.069 & 0.168 & 3.899 & 0 \\
\hline Parliament, 2017 & -0.142 & 0.069 & -0.09 & -2.077 & 0.038 \\
\hline Municipal, 2014 & -0.204 & 0.074 & -0.115 & -2.757 & 0.006 \\
\hline Municipal, 2018 & -0.101 & 0.072 & -0.059 & -1.404 & 0.161 \\
\hline \multicolumn{6}{|c|}{ Parliamentary elections, 2017 as reference } \\
\hline (Constant) & 3.433 & 0.049 & - & 70.436 & 0 \\
\hline Parliament, 2013 & 0.412 & 0.069 & 0.257 & 5.926 & 0 \\
\hline Municipal, 2014 & -0.061 & 0.074 & -0.035 & -0.825 & 0.409 \\
\hline Municipal, 2018 & 0.042 & 0.072 & 0.025 & 0.577 & 0.564 \\
\hline Parliament, 2016 & 0.142 & 0.069 & 0.09 & 2.077 & 0.038 \\
\hline \multicolumn{6}{|c|}{ Municipal elections, 2014 as reference } \\
\hline (Constant) & 3.372 & 0.056 & - & 60.262 & 0 \\
\hline Parliament, 2013 & 0.473 & 0.075 & 0.295 & 6.331 & 0 \\
\hline Municipal,2018 & 0.103 & 0.077 & 0.061 & 1.333 & 0.183 \\
\hline Parliament, 2016 & 0.204 & 0.074 & 0.129 & 2.757 & 0.006 \\
\hline Parliament, 2017 & 0.061 & 0.074 & 0.039 & 0.825 & 0.409 \\
\hline \multicolumn{6}{|c|}{ Municipal elections, 2018 as reference } \\
\hline (Constant) & 3.475 & 0.053 & - & 65.383 & 0 \\
\hline Parliament, 2013 & 0.37 & 0.073 & 0.231 & 5.096 & 0 \\
\hline Parliament, 2016 & 0.101 & 0.072 & 0.064 & 1.404 & 0.161 \\
\hline Parliament, 2017 & -0.042 & 0.072 & -0.026 & -0.577 & 0.564 \\
\hline Municipal, 2014 & -0.103 & 0.077 & -0.058 & -1.333 & 0.183 \\
\hline
\end{tabular}

